DOI https://doi.org/10.30525/978-9934-26-000-1-18

\title{
ЕТИЧНІСТЬ ВИКОРИСТАННЯ ЦИФРОВОГО СЛІДУ ЯК ІНСТРУМЕНТУ «КУЛЬТУРИ СКАСУВАННЯ»
}

\author{
Водолазька С. А. \\ доктор наук із сочіальних комунікачій, \\ доиент кафедри видавничої справи та редагування \\ Інститут журналістики Київського національного університету \\ імені Тараса Шевченка \\ м. Київ, Україна
}

Постановка проблеми. Стрімке входження людини в процес мережевої активності призводить до формування іiі як інтернеткористувача, розширює змоги та прагнення, викристалізовує відчуття впевненості та обізнаності, мотивує на здобуття та опанування інструментарію для створення дорожньої карти руху та мікровсесвіту. Водночас серфінгування просторами інтернету призводить до появи ключових цифрових атрибутів активності користувача, які залишаються поза увагою або не сприймаються серйозно - це утворення активного та пасивного цифрового сліду, цифрової тіні, які розростаються та поступово проявляють свій вплив на життєдіяльність людини, оприявнюючи відчуття явної чи прихованої залежності та, як наслідок, формуючи цифрового двійника. Накопичені цифрові дані про інтернет-користувача можуть мати подвійний резонанс і давати як корисний ефект, так i робити людину уразливою. Поетапно, під впливом повсякденних практик, модель ідеального середовища руйнується, масштабуючи загрози, перетворюючі поведінкові моделі та комунікаційні активності на поштовхи до активування процедури відторгнення, провокуючи утворення агресивно налаштованого середовища.

Метою дослідження $\epsilon$ визначення етичності використання цифрового сліду як складової цифрової репутації в контексті посилення проявів «культури скасування».

Виклад основного матеріалу дослідження. Поступово цифровий світ змінює відсоток активної присутності у реальному житті людини і починає впливати не тільки на побутовий рівень як спосіб проведення дозвілля або серфінгування інформаційними потоками, а й на соціальне та професійне життя. Результати досліджень, які публікують міжнародні рекрутингові агентства Recruiting Daily [3] та Jobvite [7] засвідчують пікові показники уваги роботодавців до мережевої активності претендента на вакансію. Масштабність і значущість явища оприявнюють статистичні дані, відповідно до яких 91-93\% рекрутерів проводять додаткову ідентифікацію потенційного працівника за профілями у соціальних 
мережах. Розміщена там інформація може скорегувати думку про людину. Оцінюючи результати відповідей рекрутерів, варто констатувати, що перебування у цифровому середовищі повинно передбачати формування усвідомленого підходу до входження в нього та розгортання активностей, які можуть залишити неоднозначно потрактовані цифрові сліди та вплинути на цифрову репутацію, яка формується на аналізі сукупності думок про людину серед користувачів інтернету.

Цифрова репутація як маркер стає ключовою основою публічності, яка спричиняє попит на дослідження мережевої активності особистості 3 потребою постійного збільшення відсотку агрегованих знань. Її комплектуванню сприяють дані, що формуються завдяки цифровому сліду та цифровій тіні, які залишають інтернет-користувачі. Цифровий слід як «digital trace» та «digital footprint». Термін цифровий слід у словниках подають у двох значеннях. У широкому значенні - це «унікальний набір цифрових активностей, дій та комунікацій, які залишають слід даних в Інтернеті або на комп'ютері чи іншому цифровому пристрої та можуть ідентифікувати конкретного користувача чи пристрій» [4]. У вузькому значенні тлумачення подане у Оксфордському словнику, де визначено, що цифровий слід - це «інформація про конкретну особу, яка існує в Інтернеті в результаті її онлайн-діяльності» [5].

Люди, попри наявність або відсутність медійного досвіду в житті офлайн, при входженні в інтернет-простір суттєву увагу приділяють оприявненню себе, створенню максимальної цифрової ідентифікації, формуванню відчуття беззаперечної публічності, виробляючи стратегію самопрезентації медійної особистості. Поступово викристалізовується «медіатизоване Я» (термін використаний Каталін Фехер): «медіатизація "Я" підкреслює процес ідентифікації, активності та поведінки в Інтернеті, а також створення цікавих історій та помилок через онлайнспілкування» [6, с. 119].

Публічність у цифровому середовищі утвердилася як тренд, який приваблює своїми перспективами та насторожує глибинною невизначеністю наслідків, провокуючи появу відчуття ейфорії від можливостей та страху від загроз. Гонитва за потраплянням до бліпів-інформації знижує вимоги до цифрової активності та збільшує потреби у генеруванні неконтрольованих цифрових слідів. Хвиля споживання симулякрів, життя за принципами еклектизму, призводить до загострення «онлайнової вразливості», яка отримала форму вираження у «культурі скасування». 2019 р. відзначився тріумфуванням терміну «cancel culture», який Google Trends назвав одним з найбільш популярних психологічних термінів, а австралійський словник «Macquarie Dictionary» визнав словом 2019 року. Така увага зумовлена збільшенням прецедентів застосування «культури скасування» у практичній площині. У 2020 році «культура скасування» стає вагомим важелем впливу на суспільство та мережеву медійну активність публічних осіб. 
Цифровий слід виявляється ключовим, але, в контексті загальноприйнятих етичних норм, неоднозначним інструментом формування практик відторгнення.

Цифровий слід при виконанні захисної, превентивної функцій в контексті «культури скасування» може виступати: як маркер проблеми для обговорення з метою демонстрування іії значущості й актуалізування необхідності вироблення спільної позиції щодо ії оцінки у суспільстві; як довготерміновий спосіб існування інформації; як публічний доказ правопорушення; як стримуючий фактор для публічних людей щодо необдуманих вчинків та висловлювань; як спосіб прогнозування поведінкової моделі публічної особистості.

Для представників радикального крила «культури скасування» цифровий слід стає доказом провини і використовується з викривальною метою. Його потрактування відбувається у довільній формі відповідно до ідеологічних потреб викривача і без додаткового вивчення контексту та обставин. Закцентовані маркери цифрового сліду декларуються у публічний простір з напередзаданим негативним емоційним забарвленням щодо суб'єкту осуду. Також реальний цифровий слід використовується як штучно змодельований привід для демонізації суб'єкта викриття, що провокує посилення негативного ставлення і формування «аури тотального відторгнення». Цифровий слід може бути застосований і у контексті формування міфотворчого медіанаративу для генерування фейкової інформації.

Практичні кейси використання цифрового сліду як інструменту «культури скасування» засвідчують наявність як позитивного досвіду, так і негативного. Наслідки такого некерованого і довільного потрактування цифрових слідів можуть впливати як на цифрову репутацію, так i на репутацію людини загалом. Маніфестом неоднозначності критеріїв «культури скасування» став матеріал «Лист про справедливість i вільні дебати» [2], що був опублікований 7 липня 2020 р. у журналі «Harper's», де група культурних та громадських діячів, описала ключові проблеми сучасного суспільства, неетичність засудження за переконання, окреслила право на «інакшу думку вголос» [2] та наголосила на необхідності припинення необгрунтованого покарання за вільне висловлення думок, стверджуючи, що існує «набір моральних настанов та політичних зобов'язань, які, як правило, послаблюють наші норми відкритих дискусій та терпимості до розбіжностей на користь ідеологічної відповідності» [2]. Підсумковою і водночас наскрізною думкою «Листа...» $\epsilon$ наголошення на наслідках: «якими б не були аргументи навколо кожного конкретного інциденту, результатом стало постійне звуження меж того, що можна сказати без загрози репресій» [2] та побоювання за «існування, якщо вони відхиляються від консенсусу або навіть не мають достатнього завзяття у згоді» [2], а також відсутності 
можливостей збереження «добросовісної незгоди без серйозних професійних наслідків» [2].

Висновки. Варто пам'ятати, що сучасний світ з його увагою до деталей і спробою глибинного осягнення історії особистості, беззаперечно вимагає напрацювання розуміння цифрової публічності та формування цифрової репутації на підставі ретельного вивчення у часовій ретроспективі потоку інформації про особистість, але беззаперечно повинні зберігатися орієнтування на етичні норми поведінки.

\section{Література:}

1. Mopi $€$. Що таке cancel culture та як люди знову опинилися по різні боки барикад. URL: https://suspilne.media/48015-so-take-cancelculture-ta-ak-ludi-znovu-opinilisa-po-rizni-boki-barikad

2. A Letter on Justice and Open Debate URL: https://harpers.org/ a-letter-on-justice-and-open-debate

3. Cocca N. 6 Tips on Succeeding with Social Recruiting in 2019. URL: https://recruitingdaily.com/6-tips-on-succeeding-with-social-recruiting in-2019

4. Digital footprint. URL: https://www.dictionary.com/browse/digitalfootprint

5. Digital footprint. URL: https://www.oxfordlearnersdictionaries.com/ definition/english/digital-footprint

6. Feher K. Netframework and the digitalized-mediatized self. Corvinus Journal of Sociology and Social Policy. 2007. № 8. C. 111-126.

7. 2019 Job Seeker Nation SurveyThe Strength of the Job Market is One-Sided. URL: https://www.jobvite.com/wp-content/uploads/2019/04/ 2019_Job_Seeker_Nation.pdf 